\title{
Revisiting the 1967 Arab-Israel War and its Consequences for the Regional System
}

\author{
Raymond Hinnebusch \\ British Journal of Middle Eastern Studies, \\ $10.1080 / 13530194.2017 .1360014$
}

\begin{abstract}
This paper examines the causes and consequences of the 1967 Arab-Israeli war utilizing Waltz's three levels of analysis, system, state and decision-makers. It first examines the causes, looking at why the MENA regional system, but particularly the Arab-Israeli subsystem, was so war prone; assessing why a certain bellicoseness was built into both Israel and several of its Arab neighbours; and assesses the calculations and miscalculations by leaders on both sides that led to war. 1967 was a "war of vulnerability" and miscalculation for Egypt but for Israel the war derived from a mix of vulnerability (from vulnerable borders) and opportunity (to acquire "defensible' borders). The paper then examines why the 1967 war did not lead to peace, but rather to a chain of new wars. Victory in 1967 reinforced Israel's territorial ambitions; shifted the power balance decisively toward it; and ultimately shattered Arab unity against it; but because the imbalance in Israel's favour was insufficient to impose a pro-Israeli peace, the result was new wars in which Arab states sought to reverse and Israel to reinforce the verdict of 1967.
\end{abstract}

Watershed wars transform the power balance and affect identities and the norms of conduct in regional states systems. The 1967 war was a pivotal event shaping the Middle East region, although it has to be paired with the subsequent 1973 war since, in important ways, these were two rounds of the same war, and it is together that their impact has to be understood. Together they did change the power balance and initiate changes in identities that reshaped the regional order. Yet despite their potential to resolve the Arab-Israeli conflict, they perpetuated it. Although ostensibly initiating a desultory peace process, they actually added new grievances and issues leading to a chain of wars that further entrenched the conflict as an intractable feature of regional politics.

What explains this? As Waltz famously argued, explanations have to be explored at three levels, system, state and decision-maker; ${ }^{1}$ but, additionally, whether a war leads to further wars depends on the kind of war and its outcome. This paper will present a framework of analysis that takes account of these factors. Guided by Waltz's three level paradigm, it will examine the 1967 war and its consequences for the region.

\section{A WALTZIAN FRAMEWORK OF ANALYSIS: TOWARD UNDERSTANDING THE 1967 WAR}

System Level 1: Creating a War System in MENA:

The post World War I "peace to end all peace" (in Fromkin's words) 2 imposed a states system on MENA that had built-in war proneness, from multiple territorial conflicts and

\footnotetext{
${ }^{1}$ Kenneth Waltz, Man, the State and War: a theoretical analysis (New York: Columbia University Press, 1954).

2 David Fromkin, A Peace to End all Peace: Creating the Modern Middle East :

1914-1922, (London and NY: Penguin Press, 1988).
} 
from the pervasive irredentism caused by the incongruence between identities and arbitrarily drawn boundaries--what Miller $^{3}$ called the nation-state imbalance. Two British demarches, the "Sykes Picot agreement," which arbitrarily divided up the Levant between Britain and France, and the Balfour Declaration, which turned over a part of it to Zionist settlers, drove and epitomized the flaws of the regional order. In observing that the Middle East states system was 'born fighting,' Buzan and Waever ${ }^{4}$ pointed to how the simultaneity of formal Arab independence after WWII and the outbreak of the first Arab-Israeli war established the major line of identity cleavage and threat around which the regional system was rapidly organized.

The Zionist project meant two peoples claiming the same land and conflict between incoming settlers and the Palestinian community was inevitable. ${ }^{5}$ The first Arab-Israeli war transformed this sub-state communal conflict into an intractable inter state conflict and created the conditions for further wars since the fighting was ended by a mere armistice that left the main issues unresolved. ${ }^{6}$

In Arab eyes, Israel was no ordinary state but an extension of the West, which, seizing much more of Palestine than the UN partition plan had assigned to it and seeking to incorporate Jews from around the world at the expense of the Palestinian Arabs, had a limitless appetite for expansion. The Arab states refused to establish normal relations with Israel and imposed an economic boycott against it; championship of the Palestinian cause became an indispensable nationalist credential for aspiring Arab political leaders.

For Israel, the war left it without readily defensible borders, while a portion of biblical Israel (the West Bank) remained in Arab hands. Security was foremost on the agenda of the new state because, although the military capabilities of the Arab states were modest, Israel's small geographic space, lack of strategic depth and encirclement by a hostile Arab world with ten times its population, led to a sense of permanent siege. Israel sought forcibly to extract recognition on its terms: Arab acceptance of its control of most of Palestine without Israeli concessions over borders or the Palestinian refugees. Continual disputes between Israel and the Arab states over poorly demarcated borders, de-militarised zones and water rights also regularly escalated into military clashes, inflaming and spreading Pan Arab nationalism which preached the idea of a common Arab nation united against Israel and its Western backers. The 1956 Suez war, a second attempt by Israel to impose its terms, ended in stalemate, but Egypt's Nasser was lionized in the Arab world for his resistance to the combined assault of Israel and the Western imperialist states, Britain and France. The 1956 war was a watershed in that it ushered in an Egypt-centric Arab order for which Egypt's Nasser, a hero of PanArab stature, could lay down the rules, largely by virtue of his ability to mobilize the "street" of most Arab countries to demand their governments follow his lead. The norms of this new order were Arab unity, anti-imperialism, and defence of the Palestine cause. The trans-state appeal of Nasserite Arab nationalism led to the overthrow of old regimes across the Arab world, replaced by radical nationalist military regimes, of which the post-1963 Ba'thist regime in Syria was the epitome, that were more

\footnotetext{
3 Benjamin Miller, "Balance of Power or the State-to-Nation Balance: Explaining Middle East War-Propensity " Security Studies 15: 4, 2006, 658-705.

${ }^{4}$ Buzan, Barry and Ole Weaver (2003), Regions and Powers: the structure of international security, Cambridge: Cambridge University Press.

5 Gerner, Deborah (1991), One Land, Two Peoples: the Conflict over Palestine,

Boulder, CO, Westview Press, 1991, pp. 11, 17-18.

${ }^{6}$ Gerner, One Land, Two Peoples, p. 49.
} 
motivated and better equipped to confront Israel and, each vying for Pan-Arab leadership, sought trusteeship of the Palestine cause as a major prize. ${ }^{7}$

\section{State Level: in-build war proneness?}

How states are constituted and regimes are designed can, in Waltz's "second image," determine their war-proneness. MENA suffers from an exceptional number of warprone states, reflective of the widespread irredentism embedded in MENA society, Indicative of that is the fact that those states that legitimize themselves on the basis of popular sovereignty are more belligerent than the Arab monarchies, whose legitimacy depends on tradition. Thus, in the Arab world, the populist authoritarian republics, the products of the deep irredentist sentiment fermenting in Arab societies, were quite war prone: although there are only nine of them they were involved 17 times in the region's 19 wars from 1946-2010. They typically came to power through revolutionary coups by nationalist military officers or alliances of the military and a radical nationalist party. As revolutionary regimes, they had a certain ideological impulse to export their revolutions regardless of the risk of provoking war. Enjoying neither democratic or tradition legitimacy, they legitimized their rule in terms of social reform and Arab nationalism and the latter required they be seen to deliver on the Arab nationalist agenda: antiimperialism, Arab unity, championing the Palestine cause. There were few constitutional checks on authoritarian presidents if they wished to pursue this agenda; indeed, the military was typically the strongest interest group, which, preoccupied with external threats, pushed for arms races, notably with Israel. These characteristics were bound to lead the revolutionary republics into wars, intended or accidental. ${ }^{8}$

But also Israel, a democracy legitimized by popular sovereignty, was similarly driven by irredentism. It has been at the centre of 8 regional wars counting the assaults on Gaza, three of which were arguably wars of choice $(1956,1967,1982)$. Israel initiated 25 of 45 militarized disputes in MENA, the world's highest frequency of such initiations relative to its period in existence. ${ }^{9}$ Arguably, this is down to Israel's special character as an irredentist settler state, which makes it both insecure and expansionist. Though more militarily powerful than the Arab states, its insecurity comes from its rejection by the Arab world combine with its initial lack of strategic depth: given the vulnerability of its borders, Israel could not afford to fight a war on its territory and had to take one into the enemy's territory before it could threaten the homeland; additionally, being reliant on the mobilisation of reserves, it could not sustain a prolonged war without great damage to its economy, hence wars had to be won quickly through overwhelming force. This resulted in a doctrine favouring a 'pre-emptive' (first

\footnotetext{
7 Michael Brecher, The Foreign Policy System of Israel, London, Oxford University Press, 1972, 251-90; Samuel J Roberts, Party and Policy in Israel, the Battle between Hawks and Doves (Boulder, CO, Westview Press, 1990), 17-21; Charles D Smith, Palestine and the Arab-Israeli Conflict, (New York, St. Martin's Press, 1996), 157-59; Steven Walt, The Origin of Alliances, (Ithaca, NY: Cornell University Press, 1987), $p$ 57

${ }^{8}$ Raymond Hinnebusch, "Explaining War in the Middle East: Deploying Waltz's Three Levels of Analysis," Lecture given at Bologna Institute for Policy Research, 7 April, 2016, http://www.bipr.eu/eventprofile.cfm/idevent=42DBFA89-BF92-BB9FF820DF2E2F8BC561/Raymond-Hinnebusch-Explaining-War-in-the-Middle-East-DeployingWaltzs-Three-Levels-of-Analysis\&zdyx $=1$

${ }^{9}$ Charles Gochman and Zeev Maoz, "Militarized Interstate Disputes," Journal of Conflict Resolution, 28: 4, 1984: 585-616
} 
strike) strategy that, given the constant tension with its neighbours, was bound to get Israel into multiple wars.

But, additionally, Israel, as a settler state, has a certain expansionist impulse built into it. According to the Law of Return, Diaspora Jews have a right of citizenship and Israeli policy actively promoted Jewish emigration, often settled on land from which Palestinians were dispossessed.10 Absorbing a growing population in an arid land led Israel to seek greater control over regional water resources, initiating projects to divert the waters of the Jordan River in the 1960s that the Arabs took as a provocation and a bid to further emigration. The pressure for more land was reinforced by dissatisfaction among many Israelis with the incomplete Judaization of the territory of ancient Eretz Yisrael and the consequent belief among militant nationalists that the completion of the Zionist project required the incorporation of 'Judea/Samaria'--before 1967 the Jordanian-controlled 'West Bank' of the Jordan River. Thus irredentism, insecurity and expansionism built war proneness into the fabric of the Israel state.

\section{The Impact of the 1967 War: Kind and Consequences}

While states' built-in war proneness predispose the region to chains of wars, whether a war leads to more war or not depends in good part on the kind of the original war and its outcome.

1967: what kind of war? Janice Stein ${ }^{11}$ distinguishes wars of vulnerability, in which leaders perceive they have "no choice" from "wars of choice" or of opportunity; realists distinguish defensive realist states that only seek a sufficiency of power to deter enemies and get into wars unwillingly from offensive realists seeking hegemony that wage wars of choice. This overlaps with Schweller's ${ }^{12}$ distinction between status quo states that value what they have more than what they might get in a war vs. revisionist states that value what they might get in war over what they have.

At first sight, the 1967 war appears, as Stein argues and others concur, to be a war of vulnerability on both sides, with neither seeking a war but events spiralling out of control. Most accept that Nasser stumbled into war from miscalculation and that he was entrapped by Pan-Arab outbidding into a showdown in which he hoped to make political gains but to avoid war, counting on superpower intervention which did not materialize. 13

For Israel the 1967 war was, on the face of it, a the classic defensive war fought for security: on the eve of the war, Israel was surrounded, Egypt had provided several causus belli and the war is usually described as a pre-emptive one; Israel struck first because war seemed inevitable. And yet the evidence is clear that Israel was not

\footnotetext{
10 Yorum Peri, 'From political nationalism to ethno-nationalism: the case of Israel,' in Yehuda Lukas and Abdalla M. Battah, The Arab-Israeli Conflict, Boulder CO, Westview Press, 1988:44; Gerner, One Land, Two Peoples, p 59.

${ }^{11}$ Janice Gross Stein, "The Arab-Israeli War of 1967: Inadvertent War Through Miscalculated Escalation" in Alexander George, et. al, Avoiding War: Problems of Crisis Management (Boulder, CO: Westview 1991), pp. 126-59.

12 Randall L. Schweller, "Bandwagoning for Profit: Bringing the Revisionist State Back In." International Security 19:1 (Summer, 1994), pp. 72-107. ${ }^{13}$ Avi Shliam, The Iron Wall: Israel and the Arab World, (London: Penguin 2001), 236,242; Richard B. Parker, The Politics of Miscalculation in the Middle East (Bloomington IN: Indiana University Press, 1993); Michael Barnett, Dialogues in Arab Politics: Negotiations in Regional Order (New York, Columbia University Press, 1998), pp. 146-59.
} 
seriously threatened militarily. Popp, ${ }^{14}$ on the basis of recently de-classified information, shows that 1967 was a war of choice, and that Israel had a premeditation to commence hostilities since the balance of forces made a military defeat virtually impossible. The Israeli generals were "spoiling for a fight" ${ }^{15}$ Even less was it a preemptive war--heading off an Egyptian attack--since Egypt had no intention of attacking. ${ }^{16}$ As Prime Minister Begin later admitted: "In June 1967, we again had a choice. The Egyptian Army concentrations in the Sinai approaches do not prove that Nasser was really about to attack us. We must be honest with ourselves. We decided to attack him." 17 A good part of the Israeli rationale, however, was to acquire defensive borders. 1967 was a "war of vulnerability" and miscalculation for Egypt but for Israel the war derived from a mix of vulnerability (from vulnerable borders) and opportunity (to acquire “defensible' borders).

The consequences of war outcomes for state orientations: The outcome of wars helps determine whether there will be a peace settlement or another war. Neo-realism expects lost wars to socialize states into the rules of the game, inducing greater prudence: tailoring ambitions and subordinating ideology to the calculations of the balance of power; conversely, victory in war could, in principle, stimulate ambition and over-confidence in the utility of war, and states would be more likely to overreach themselves, increasing the likelihood of war. However, realism also expects that the imbalances resulting from a defeat would stimulate efforts to right the power imbalance by the losing side, potentially restoring deterrence on both sides.

If we combine the kind of war with its outcome, we get several permutations. A victorious war of choice by a revisionist power is likely to reinforce revisionism and chances of further war; but victory in a war of vulnerability by an insecure power may reduce insecurity, enabling peace. Defeat of an revisionist power in a war of choice is likely to reduce revisionism but defeat of a insecure power will increase its sense of vulnerability, which could either make it either more risk averse or drive it to build up its capacity and reverse the verdict of defeat. Stalemate in war leaves an indeterminate impact on states' orientations.

It takes two to make a war and whether there is another one depends on the impact of war on both states: so what might we have expected from the outcomes for both sides in 1967 and 1973? Other things being equal, the differential experience of 1967--a humiliating loss for the Arabs, an exhilarating victory for the Israelis, ought to have had diverging impacts. Victory was likely to reinforce Israeli ambitions and its belief in the utility of war while defeat was likely to have tempered Arab revisionism-but not necessarily enough to make them accept Israeli terms. The 1973 war, in which there was no clear victor or defeated ought, on the other hand, to have produced a certain convergence toward prudence on both sides and might have led to peace-yet it did not. To explain why, other factors, such as the systemic level power balance and the calculations of individual leaders and their governing coalitions have to be taken into account.

\footnotetext{
${ }^{14}$ Roland Popp, 'Stumbling Decidedly into the Six-Day war, 'Middle East Journal, 60:2, spring 2006.

15 Martin van Creveld, The Sword and the Olive Branch: a Critical History of the Israeli Defense Force (New York: Public Affairs, 1998), pp. 172, 297.

16 Jeremy Hammond, 'Israel's Attack on Egypt in 1967 war not 'pre-emptive,' Foreign Policy Journal, July 4, 2010, http://www.foreignpolicyjournal.com/2010/07/04/israels-attack-onegypt-in-june-67-was-not-preemptive/

17 http://www.nytimes.com/1982/08/21/world/excerpts-from-begin-speech-at-nationaldefense-college.html)
} 
System Level II: The Occasions of War and the Balance of Power

The power balance shapes whether states perceive war as a viable option. When a stable balance exists, if the power of both sides is equal, neither should be sure enough of winning a war to initiate one (unless they feel they have no choice), while a major stable imbalance should deter war by the weaker side. The region is, however, susceptible to sudden shifts in the balance of power because of its high level of militarization and arms races funded by states' exceptional access to revenues from oil (Arab states) or foreign aid (Israel) and the willingness of great power patrons and arms merchants to provide arms. Such an unstable power balance encourages miscalculations (exaggerating threat or exaggerating ones own capabilities) that may lead to war. Moreover, as the power transition school argues, ${ }^{18}$ the most dangerous situation is when a rising second rank dissatisfied power approaches the power capabilities of a superior power; the latter may try to pre-empt this via war or the former (mis)-calculate that it's best chance has arrived. Lemke finds that the combination of dissatisfaction and near-power parity increased the chance of war in MENA by $76 \% .^{19}$

Wars, once fought, may not just alter the power balance in favour of the victor, but also wars over hegemony in a region may transform it; at the same time, however, neo-realism expects states to combine against and prevent a rising hegemon, unless its bid has some legitimacy and is seen as likely to deliver public goods for a region; in MENA, however, aspirant hegemons have always been checked by counter-balancing. ${ }^{20}$

How does this relate to Arab-Israeli wars? 1967 approximated the power transition scenario in that the Arab states seemed to be approaching parity with Israel, hence a "preventive" war by the latter aimed to forestall this. After 1967 the power balance was dramatically altered in favour of Israel; however, this stimulated efforts on the part of Israel's neighbours to right the power balance (rebuilding of the shattered Egyptian and Syrian armies) which, to a degree succeeded so that again on the eve of the 1973 war the power transition scenario could be said to have been restored. 1973 seemed to establish a balance that might have been favourable to a peace settlement, but Egypt's separate peace again upset it in Israel's favour, enabling Israel's 1982 invasion of Lebanon. But once again its Arab rivals found ways of restoring some balance (Syria's reach for "strategic parity; Hizbollah's "asymmetric warfare"). Israel's 1982 bid for military hegemony failed and was replaced by a certain mutual deterrence; yet in other respects the power transition scenario still held as arms races amidst unresolved grievances continued. This history shows us that power balancing will often fail to prevent war, but it does prevent victors from establishing hegemony since losing states mobilize the capabilities and allies to blunt aggression or when, after a first war they fall sharply behind, they redress the power imbalance. The lesson of the ArabIsraeli conflict seems to be that, so long as deep grievances remain unsatisfied, systemic conditions - the power transition scenario--continues to lead decision-makers to think that they can use war to impose their terms; yet because in reality no side is strong enough to do this, war after war continues to be waged.

18 Organski, A. F. K. World Politics. 2d ed. New York: Knopf, 1968

19 Douglas Lemke, Regions of War and Peace, Cambridge 2002, pp. 118-25

${ }^{20}$ Raymond Hinnebusch, "Failed regional Hegemons: the case of the Middle East's Regional Powers," Journal of Diplomacy and International Relations, 14:2, 2013, 70-86 
This is provided, of course, that both sides have the resources to continue the contest. As noted above, regional states are readily able to acquire arms (and asymmetric warfare does not require much sophisticated hardware). Here the role of the global level great powers, which have typically been patrons of regional states, matters. In MENA the record is that global patrons both contain war by exercising restraint over clients yet also provide the latter with the means of war- creating arms races. Post-war, a defeated client may be buffered from the consequences of war; thus, the Soviet Union's rearmament of Egyptian and Syrian armies (backed by Gulf Arab funders) enabled these states to avoid submission to Israeli peace terms; on the other hand, the US, impressed by Israeli war prowess in 1967, thereafter viewed it as a "strategic asset" (not a liability that had to be protected) and adopted a policy of arms deliveries to keep Israel stronger than all of the Arab states combined. The consequence was the reproduction of the power transition scenario. If, additionally, patrons cease to restrain their clients, war becomes likely, as happened in 1967 (failure of US restraint of Israel), 1973 (failure of Soviet restraint of the Arabs) and 1982 (failure of US restraint of Israel).

\section{Individual Level: hawks vs. doves}

The strategies, calculations and personalities of leaders (e.g. aggressive personalities) and ruling coalition interests (e.g. domestic legitimacy needs) can make a difference if other conditions are evenly balanced for and against war. Leaders famously miscalculate, either exaggerating threat or their own capabilities, as Nasser famously did in 1967. Changes in leadership are likely in war-losing states where more pragmatic, cautious leaders emerge (Sadat and Asad); where states were victorious, they might feel more secure, but hardliners are empowered and ambitions expand (Begin, Sharon). The balance between rival coalitions can shift calculations, too. In the Arab case, the Arab nationalist ideologues of the sixties were eclipsed after 1967 by pragmatists prioritizing state interests. The 1967 war, in giving Israeli control of the occupied territories, radically empowered irredentists intent on settling these territories-the single most important factor in obstructing peace and generating a chain of wars. Where wars end in stalemates, such as 1973 and 1982, the domestic power struggle between dovish and hawkish coalitions may be decisive for whether there is soon another war; in Israel the fact that the Likud was able to take advantage of a perception that the Labour Party had not won the 1973 war paved the way for electoral shifts that led to the 1982 war.

\section{APPLYING THE WALTZIAN FRAMEWORK TO THE 1967 WAR AND ITS AFTERMATH}

\section{The drivers of the 1967 War}

In the following section, the historical evolution of the events leading to the 1967 war and its aftermath will be traced, informed by the previous Waltzian framework.

\section{Arab regional dynamics:}

Israel's attack on its neighbours unleashed the war but it was the dynamics of PanArabism which gave Israeli hawks the opportunity to realise their ambitions; 
specifically, Nasser's need to protect his Arab leadership against challenges from both the left and the right led him into fatal brinkmanship in the spring of 196721

From the mid-1960s, Egypt, as Pan-Arab leader, was under growing pressure to act against Israel's diversion of the Jordan River. Also, the Palestinian refugees were increasingly impatient for Arab action to resolve their plight; indeed, newly founded groups such as al-Fatah launched a guerrilla struggle against Israel that they hoped would detonate a wider Arab-Israeli war. Nasser argued that the Arab world had to build up its forces, modernise and unify before it would be ready for confrontation with Israel and, with his best forces tied down in the Yemen civil war, he could hardly afford a war. But his Arab rivals, particularly Syria, used the issue to put him on the defensive ${ }^{22}$

The Syrian-Israeli conflict dated back to differences over the de-militarised zones established by the 1948 armistice. Israel's 'creeping annexation' of these zones ${ }^{23}$, Syrian shelling of the paramilitary settlements Israel implanted in them, and the resulting massive Israeli retaliation, generated a particularly radical version of Arab nationalism in Syria and was a factor in bringing the Ba'th party to power in 1963. The radical but narrow based Ba'thist regime began championing the Palestine cause to win domestic legitimacy and outbid Nasser for Pan-Arab leadership. To contain revisionist Syria, Nasser initiated Arab summit meetings to spread responsibility for inaction among the Arab leaders. The summits agreed to counter Israel by diverting the Jordan River sources, which, since these rose in Syria, would force Damascus to bear the consequences of its own militancy. However, the Syrian Ba'th use Israeli attacks on its diversion works to embarrass Nasser, criticising the UN buffer force in the Sinai (UNEF) which prevented him from deterring Israel. Saudi Arabia, at odds with Egypt over Yemen, taunted Nasser for having troops in Yemen when they were needed against Israel. Syria took advantage of this to entice Nasser into a radical Cairo-Damascus axis. While Nasser hoped this would remove Syria's incentive for nationalist outbidding, Damascus viewed it as the essential backing for its sponsorship of Palestinian guerrilla warfare against Israel. This fedayeen action was the immediate precipitant of the escalation that would lead to war. ${ }^{24}$ It also prepared the ground for bringing Jordan into the Arab coalition encircling Israel. An Israel raid on Jordan because of guerrilla attacks sponsored by Syria had convinced King Hussein that Israel did not reward moderation. He responded to the Cairo propaganda attacks that were stirring up his population by goading Nasser for his inaction, helping to bring about the inflamed crisis of May 1967 in which aroused public opinion forced him to stand against Israel. Even knowing it could cost him his territory and army, domestic pressure left Hussein no choice but to align with Egypt and Syria as war approached ${ }^{25}$.

That crisis was provoked when in May 1967 Israeli retaliations for guerrilla incursions by Syrian-backed Palestinians climaxed in an Israeli threat to attack and overthrow the Syrian regime. The Soviet Union prodded Nasser to deter Israel and, as leader of the Arab world, he felt obliged to do so. Nasser realised the power balance,

\footnotetext{
${ }^{21}$ Janet Stein, 'The security dilemma in the Middle East: the prognosis for the decade ahead,' in Bahgat Korany, Paul Noble, Rex Brynen, The Many Faces of National Security in the Middle East, London, Macmillan, 1993, 62-7; Barnett, Dialogues in Arab Politics, 153-159. ${ }^{22}$ Avraham Sela, The End of the Arab-Israeli Conflict: Middle East Politics and the Quest for Regional Order, Albany, NY, State University of New York Press, 1998: 52-53, 78).

${ }^{23}$ Gerner, One Land, Two Peoples, p. 70.

${ }^{24}$ Steven Walt, The Origin of Alliances (Ithaca, NY: Cornell University Press, 1987), pp. 86-7; Sela, The End of the Arab Israel War, pp. 75-90; Malcolm Kerr, The Arab Cold War: Jamal Abd al-Nasir and his Rivals, 1958-1970 (London, Oxford University Press, 1971) pp. 96-128.

${ }^{25}$ Stein, "The Security Dilemma," 65-66
} 
with his best forces tied down in Yemen, was unfavourable and did not, therefore, want a war but he could not remain passive. He therefore requested UN withdrawal from the Sinai and sent troops into the peninsula as a deterrent and with defensive instructions that assumed an Israeli first strike. Israel abandoned plans for an attack on Syria but began a counter-mobilization, which put it in a position to launch a more general war. ${ }^{26}$ Nasser could have de-escalated but he allowed himself to be pushed into further brinkmanship by the expectations raised by his own nationalist rhetoric. Seeing a chance to win a political victory and perhaps extract some concessions from Israel on the Palestinian issue, he closed the Straits of Tiran to Israeli shipping. Popular euphoria that the Arabs were finally confronting Israel swept the front line states into a defence pact encircling Israel.

Nasser overplayed his hand in the crisis of spring 1967 in part because he had become complacent about his ability to manipulate bi-polarity. Nasser's defence minister, General Shams ad-Din Badran apparently misled him into believing the Soviets had promised intervention to deter Israel; but, in fact, it was Moscow that would be deterred when war broke out by fear of a confrontation with the US. With the Suez precedent in mind, Nasser miscalculated that the US would restrain Israel for fear a war would inflame Arab opinion against the West or bring confrontation with the USSR. Moreover, Nasser had given the US a commitment that Egypt would not be the one to initiate war and was led to think that the US was trying to broker a negotiated settlement of the crisis that would give him a Suez like political victory. However, in Washington, Lyndon Johnson, a friend of Israel, failed to restrain Israel's march to war. In essence, the Arab-nationalist 'outbidding' in which the rival Arab states had engaged was leading them into a war none wanted. 27

\section{Israeli realpolitik calculations}

As Israel started the war by striking first, understanding the war means understanding its motives. Because Israel's superiority was problematic if the Arab forces effectively combined and forced a multi-front war on it, preventing such a combination was a constant of Israeli policy and this required a pro-active military stance: Israeli war doctrine aimed at quickly smashing the enemy and, in a multi-front war, neutralising one opponent quickly in order to cope with the other/s. Since collective Arab action had normally been a function of Egyptian success in uniting the Arabs and, particularly coordinating with Syria and Jordan, Israel considered a whole range of Egyptian-initiated actions to be a casus belli justifying a first strike, notably the concentration of Egyptian forces in the Sinai and the ascendancy of Egyptian influence over Jordan: the Israeli 1967 first strike, responded to such an emerging scenario. Once Israel began to mobilise, at economic cost, it would not long wait for diplomacy to end the closure of the Straits. Moreover, since weapons, particularly aircraft, were vulnerable while no country enjoyed much strategic depth, a first strike could give decisive advantage. Yet, the actual military threat to Israel was moderate: Nasser had no intention of striking first, the Israeli generals were confident of victory and the CIA backed their assessment. Insofar as there was a threat, it was more political than military: a superpower-

\footnotetext{
${ }^{26}$ Sela, The End of the Arab-Israeli Conflict pp. 91-93; Gerner, One Land, Two Peoples, p. 71; Fawaz Gerges, The Superpowers and the Middle East: Regional and International politics, 19551967, Boulder, CO, Westview Press, 1994, p. 213; Stein, “The Security Dilemma," 64.

27 Gerges, The Superpowers and the Middle East, pp. 218-25.
} 
brokered resolution of the crisis that could strengthen Nasser and further embolden the Arabs. $^{28}$

Israeli elites were initially split over war. An activist camp, dominant in the military and led by disciples of Ben Gurion, such as Moshe Dayan, were convinced that Israel enjoyed the decisive military superiority to take on the enemy): the crisis was less a threat that an opportunity--to smash Nasserist Egypt and the Pan-Arab movement while Israel still had military superiority, to achieve secure borders by seizing "buffer zones," and to force the Arabs to accept Israel. In power transition terms, Israel would check rising Arab power before the Arabs demographic advantage could be translated into military power. At the same time, the irredentist Herut party of Menachem Begin saw the crisis as an opportunity to realise Eretz Yisrael and it had its advocates in the military. ${ }^{29}$ The moderate Prime Minister Levi Eshkol wished to rely on American diplomacy to defuse the crisis and was adverse to a pre-emptive strike but he succumbed to military pressure and the hawks took charge of actual military decisionmaking. Pre-emption was Israel's historic strategy and the main restraint on it had always been fear of the international repercussions, but in June 1967 the international situation was unusually permissive with the US abdicating its former role in restraining Israel. Although far from evident to the Arabs, the imbalance of power in Israeli's favour remained substantial and Israel's first strike was entirely rational. ${ }^{30}$

\section{The consequences of the 1967 War:}

\section{Transformed power balance?}

The war ushered in major alterations in the Arab-Israeli balance of power and re-drew the regional map to Israel's advantage. Israel not only decisively defeated the Arab armies but also seized the Sinai Peninsula and Gaza Strip from Egypt, the Golan Heights from Syria and the Palestinian populated 'West Bank' from Jordan. In upsetting the status quo, the war might have led to an Arab-Israeli peace. UNSC resolution 242, jointly sponsored by the superpowers in the aftermath of the war, provided an internationally accepted framework for a settlement. It amounted in essence to a proposed trade of 'land for peace'; in linking the inadmissibility of the acquisition of land by conquest to a call for all states in the region to be recognised as having the right to live in peace, it affirmed that the Arab states would now have to finally accept the existence of Israel and Israel would have to withdraw from the territories it had seized. Although Israel denied the resolution required it to withdraw from all the territories, all other states, including the U.S., interpreted the resolution to mean virtually complete withdrawal. ${ }^{31}$

The 1967 war also unleashed a major transformation in Arab attitudes to Israel. To be sure, in the short term, the conquest of the 1967 territories further locked the Arab states into the conflict with it. The defeated Arab nationalist regimes could not yet overtly accept a directly negotiated peace settlement and wanted a UN-sponsored end

\footnotetext{
${ }^{28}$ Brecher, The Foreign Policy System of Israel, pp. 51, 67; Gerner, One Land, Two Peoples, pp. 7172; Smith, Palestine and the Arab-Israeli Conflict, 199.

${ }^{29}$ Brecher, The Foreign Policy System of Israel, 247; Roberts, Party and Policy in Israel, p. 36; Smith, Palestine and the Arab-Israeli Conflict, 1996, p. 192.

${ }^{30}$ Brecher, The Foreign Policy System of Israel, p. 552; Smith, Palestine and the Arab-Israeli Conflict, pp. 196-202; Sela, The End of the Arab-Israeli Conflict, pp. 91-3; Barnett, Dialogues in Arab Politics, pp. 14659; Yoram Peri, Between Battles and Ballots: Israeli Military in Politics, (Cambridge, Cambridge University Press, 1983), pp. 244-251; Kimsche, David and Dan Bawly, (1968), The Sandstorm: The Arab Israeli War of June 1967: Prelude and Aftermath, (N.Y., 1968), pp. 45, 57, 62, 69).
}

${ }^{31}$ Smith, Palestine and the Arab-Israeli Conflict, pp. 211-213. 
to belligerency and Israeli withdrawal. But they were under no illusion that they could avoid a formal peace treaty if they were to recover their lost lands. Despite some shortterm inflammation of radical public sentiment, the 1967 defeat, in giving a mortal blow to Pan-Arab dreams, started the process of Arab acceptance of the permanence, if not the legitimacy, of Israel. Egypt's defeat precipitated a realist pragmatism in the hegemonic Arab state as Nasser himself began looking to mend relations with the US and to find a diplomatic solution to the Israeli occupation. ${ }^{32}$ Asad's rise in Syria marked a similar moderation of nationalism there. Radical Arab states that had challenged Israel on behalf of the Palestine cause, in disregard of the power imbalance against them, were 'socialised' the hard way into the rules of realist prudence needed to survive in a dangerous states system. King Hussein's 1970 crushing of the Palestinian fedayeen's attempt to turn Jordan into a base of operations against Israel was another watershed that started the gradual moderation of the PLO leadership: it would soon reduce its goal to the establishment of a Palestinian state in the West Bank and Gaza. To be sure, as the chance of a diplomatic settlement faded in the years after 1967, the survival of the front line regimes would require they re-vindicate themselves against Israel: they could not rest until the occupation of their territory, touching on vital state and regime interests more directly than the Palestine cause had ever done, was rolled back. However, as the notion of the liberation of Palestine gave way to the aim of recovering the occupied territories, an irreconcilable 'existential' conflict between the two sides was gradually transformed into a limited one over territory that was much more amenable to a compromise settlement. ${ }^{33}$

Unfortunately, if 1967 marked the beginning of the end of Arab nationalist revisionism, it had the opposite effect on a triumphant Israel. Although the military hegemony Israel achieved in the war gave it cause to feel more secure, the success of a military solution to its insecurity not only reduced its motivation to reach a permanent settlement with the Arab states but actually whet its irredentist appetites. Israel insisted that a peace settlement would require the Arab states to accept direct negotiations and that it was unprepared to return to the 1967 lines. It wanted to keep strategic parts of its conquests that it insisted were needed to give it 'secure borders' including the Golan Heights, control of the Jordan River Valley, and parts of the Sinai). Additionally, the simultaneous rise of an irredentist right-wing settler movement and of the Likud party, which, beginning in 1977, started to win elections, propelled attempts to colonise and incorporate the territories even though this meant permanent repressive rule over a large Palestinian population in violation of international law. ${ }^{34}$ The settlement drive decisively obstructed the potential to trade the occupied lands for peace. In essence, the 1967 war did not result in the compromise settlement outlined in UN Resolution 242 because the power asymmetry gave the Israelis no incentives to concede it and the Arab states no capacity to extract it. As a result, 1967 set the stage for three more wars in the space of about a decade, the Egyptian-Israeli War of Attrition (1969-70), the 1973 Arab-Israeli war and the 1982 Israeli invasion of Lebanon. ${ }^{35}$

\footnotetext{
32 Gerges, The Superpowers and the Middle East, pp. 228, 236

33 Sela, The End of the Arab-Israeli Conflict, pp. 27-30, 97-109; Smith, Palestine and the ArabIsraeli Conflict, pp. 235-237.

${ }^{34}$ Ilan Peleg,'The impact of the Six-Day War on the Israeli right: a Second Republic in the making?,' in Lukas and Battah, The Arab-Israeli Conflict, p 60; Peri, "From Political Nationalism;" Roberts, Party and Policy in Israel, pp. 25-30

35 Gerner, One Land, Two Peoples, pp. 72-75; Smith, Palestine and the Arab-Israeli Conflict, pp.

201, 208-211, 228-230.
} 
The Arab states system from Arab triangle to the 1973 War

Another effect of the 1967 war was to transform the Arab system from the Egyptcentred Pan-Arab one to what Ajami called the 'Arab Triangle.' ${ }^{36}$ Nasser's death and replacement by Sadat overnight reduced Egypt from hegemon of the Pan-Arab order to the status of a 'normal' state. Egypt had never had the resources of a well-rounded hegemon, either the ability to project military power in the Arab world or the economic superiority to provide much in economic rewards and by the late sixties, the costs of hegemony--first from Yemen, then from the 1967 defeat--were impoverishing the country while the growing oil revenues accruing to the oil monarchies was shifting the balance of economic power to them. Cairo's hegemony had been based largely on the ideological appeal of Arabism, but this was shattered by the 1967 defeat while growing state formation made other states less permeable to Pan-Arab ideological penetration from Cairo. President Anwar Sadat, Nasser's successor, having neither the will nor PanArab stature to continue Nasser's Pan-Arab role, subordinated all other concerns to the recovery of the occupied Sinai. The Egypt-centric Pan-Arab order which could be said to have been founded by the outcome of the 1956 Suez war lost the hegemon that had enforced and held it together as a result of the 1967 war.

With the decline of the Egyptian hegemon, other Arab states acquired greater freedom to pursue state interests but those interests were now shaped by the muchincreased threat from Israel. Before 1967, the expectation that the great powers would restrain Israel, the greater immediate fear of subversion by Arab rivals, and the little practical possibility of liberating Palestine had deterred effective alliance building against Israel; afterwards, a militarily preponderant and expansive Israel had to be contained while the occupied territories were potentially recoverable. This was only possible through inter-Arab co-operation and the much-reduced ideological threat of Cairo made this co-operation less risky for the other Arab states. Thus, Israel's military preponderance sparked an effort on the Arab side to balance it through alliance formation and military build-up. ${ }^{37}$

Egypt was still the pivotal Arab state and the natural leader of an Arab coalition against Israel, but it had now to lead by consensus. Gradually Egypt and Syria, under new pragmatic leaders, were thrown together by their common interest in a war for recovery of the occupied territories while Saudi Arabia took advantage of their need for financial backing to moderate their policies and achieve full partnership in core Arab affairs. If no one state had enough assets to play the Arab hegemon, an axis of the largest (Egypt), the richest (Saudi Arabia), and most Pan Arab (Syria) states could pool complementary resources and forge an Arab consensus on war and peace. This 'Arab Triangle' would, for a period, replace Egyptian hegemony as a new basis of Arab cohesion, allowed by the greater equality, hence trust, between the main leaders, Sadat, Asad and Feisal. ${ }^{38}$

The three leaders began exploring two tracks for the recovery of the occupied territories. Egypt and Syria continued re-building their armies with Soviet arms financed by Arab oil money, while Sadat and the Saudis tried to enlist American pressure on Israel for a diplomatic settlement. Nasser's acceptance of the Rogers Plan had laid the grounds for a settlement and Sadat made new efforts to enlist US help in reaching one. However, another Arab-Israeli war became inevitable when the US

\footnotetext{
${ }^{36}$ Ajami, Fouad, (1977-78), 'Stress in the Arab Triangle,' Foreign Policy, no. 29, pp. 90-108.

37 Walt, The Origin of Alliances, pp. 117, 120-121. 265-66.

38 Ajami, Arab Triangle; Alan Taylor, The Arab Balance of Power, Syracuse, NY: Syracuse University Press, 1982). 49-56; Sela, The End of the Arab-Israeli Conflict 142-145, 148.
} 
rebuffed Sadat's diplomatic initiatives: in October 1973, Egypt and Syria launched a coordinated attack on the Israeli-occupied territories while Saudi Arabia deployed the oil weapon to force the intervention of American diplomacy. ${ }^{39}$

\section{The 4th Arab-Israeli War of 1973:}

The conduct and outcome of the 1973 war were both shaped by and reshaped the ArabIsraeli power balance. On the one hand, tactically, Egypt's fears about Israeli air superiority led it to adopt a flawed war plan aiming at the mere seizure of a strip of land on the East bank of the Suez Canal (in order to break the diplomatic stalemate); this allowed Israel to concentrate first on its northern and then its southern fronts, forfeiting the advantage of the two-front joint Egyptian-Syrian assault. When a cease-fire was called, the Egyptian army was still clinging to its foothold in the Sinai, but Israeli forces were entrenched on the West bank of the canal and the Egyptian Third Army surrounded and in bad need of American intervention to restrain Israeli violations of the cease-fire and bring about a disengagement of forces. While tactically, Israeli emerged from the war with the upper-hand, the war altered the strategic power imbalance that had deprived the Arabs of all leverage to negotiate an acceptable settlement with Israel. The Arab armies failed to liberate the occupied territories, but their ability to challenge Israel and inflict high costs on it and the oil embargo, in threatening vital Western interests, sufficiently upset the status quo to force American intervention on behalf of a negotiated settlement. At the same time, the relative Arab success in the war (compared to 1967) endowed the frontline states with a legitimacy windfall that made it less politically risky for them to move toward a peace settlement. Arab summits following the war, led by the 'Arab Triangle' powers, legitimised a 'comprehensive peace' with Israel in return for its full withdrawal from the occupied territories and the creation of a Palestinian state in the West Bank and Gaza. They also designated the PLO as the sole representative of the Palestinians in peace negotiations. Arguably, the war gave the Arab states increased leverage to extract the settlement they wanted if they stuck together and played their cards right. Israel, for its part, had an interest in a partial settlement, that is, one with Egypt, if that left it free to avoid political settlements on its other fronts. ${ }^{40}$

A new Arab order-stillborn: The 1973 war seemed to revive the defunct PanArab system, albeit in new form. The war caused a massive resurgence of Arab nationalism that drove all Arab states to close ranks behind Egypt and Syria: Iraqi and Jordanian forces played crucial roles in containing Israeli counteroffensives against Syria while Morocco and Saudi Arabia sent token contingents to the front lines and Algeria and the Gulf states provided finance for Soviet arms deliveries. ${ }^{41}$ Not just the shared threat but also a shared resource, the new oil wealth from the price boom unleashed by the oil embargo, generated interdependence between the Arab states. The expectation that the new wealth would be shared with the states that had fought and sacrificed for the common Arab cause was partly realised by significant transfers of wealth to the latter, the migration of excess labour to the labour scarce Arab oil producing monarchies and the transfer of remittances home. The 'Arab Cold War' was decisively buried as the conservative oil monarchies used aid to moderate the

\footnotetext{
39 Walt, The Origin of Alliances, pp. 117-121; Edward Sheehan, 'How Kissinger did it: step by step in the Middle East,' Foreign Policy, 22, 1976, 3-70; Muhammed Hassanein Heikel, The Road to Ramadan, NY: Reader's Digest Press, 1975; Smith, Palestine and the Arab Israeli Conflict, pp. 226-228.

${ }^{40}$ Sela, The End of the Arab-Israeli Conflict, pp. 211-213.

${ }^{41}$ Sela The End of the Arab-Israeli Conflict, p. 145.
} 
radicalism of the nationalist republics and ideological subversion and media wars gave way, in inter-Arab affairs, to inter-state diplomacy. 42

Consolidation of the individual states meant their increased ability to put state sovereignty over Arabism. If the 1973 war and associated oil boom fuelled inter-Arab interdependencies, at the same time relative wartime success restored some of the legitimacy of the individual states and the new oil money fostered state building. The distribution of oil revenues across the system allowed states to build large armies and bureaucracies, generate new bourgeoisies with a stake in regimes, and co-opt the middle class, which, once the constituency of Arabism, now became or aspired to be part of the new state establishments. The very durability of the states as the customary framework of political life fostered their growing acceptance, if not strong affective support for them. States became far less vulnerable to Pan-Arab penetration as the PanArab movements, once so readily manipulated by Nasser against his rivals, virtually disappeared or were 'statised:' thus Ba'thism became the official ideology and the Ba'th party an instrument of state co-optation in Syria and Iraq. ${ }^{43}$

\section{The Shattering of the Arab Triangle: Egypt's Separate Peace:}

Just as the conflict with Israel gave birth to the Arab triangle, so disagreements over the conflict's resolution destroyed it as, after the 1973 war, Egypt's Sadat proceeded stepby-step, down the road to a separate peace at the expense of his Arab partners. Knowing Israel was prepared to trade the bulk of the Sinai for a peace that would remove Egypt, the strongest Arab state, from the Arab-Israeli power balance, and that if he stuck with Syria and the PLO in insisting on a comprehensive settlement and a Palestinian state, that he might get nothing, Sadat entered into negotiations at Camp David for what would be a separate peace. For Israel's Begin, the Sinai was a price worth paying since, as it became apparent that Sadat would abandon the Palestinians, he saw the chance to keep the West Bank. While ostensibly the Camp David agreement provided for Palestinian 'autonomy,' the subsequent failure of this to be realised did not deter Sadat from signing a separate peace with Israel in 1979. At the second Baghdad summit, Iraq and Syria jointly forced Saudi Arabia and other wavering states to ostracise Egypt. This, in forcing Egypt into greater dependence on the U.S., allowed the virtual neutralisation of the core Arab state by a superpower deeply biased toward Israel. 44

The relative Arab-Israeli power balance resulting from the 1973 war meant neither side could hope to impose its will, hence each had an incentive to seek a diplomatic solution. This chance was, however, missed, in part because US arms deliveries to Israel and Egypt's separate peace, restored Israel military superiority. This not only reduced its incentive to reach a comprehensive peace but radically upset the regional power balance as well. Egypt's opting out of the Arab-Israel power balance amounted to a form of 'buck-passing,' a practice that enervates the alliance stability needed to deter powerful states. In this case, the resulting power imbalance would lead directly to the fifth Arab-Israeli war of 1982.

\footnotetext{
42 Ali ad-Din Hillal Dessouki, (1982), 'The new Arab political order: implications for the eighties,' in eds, Malcolm Kerr and El Sayed Yassin, Rich and Poor States in the Middle East, Boulder, CO, Westview Press, 1982, 319-47; Barnett, Dialogues in Arab Politics, p. 153.

${ }^{43}$ Paul Noble, 'The Arab system: pressures, constraints, and opportunities,' in

Bahgat Korany and Ali E. Hillal Dessouki, The Foreign Policies of Arab States: 1991: the Challenge of Change, Boulder CO, Westview Press, 41-78.1991: 65-70; Barnett, Dialogues in Arab Politics, p. 183; Sela, The End of the Arab-Israeli Conflict 148-150.
}

${ }^{44}$ Smith, Palestine and the Arab-Israeli Conflict, pp. 256-258. 
Sadat's move toward a separate peace had, from at least the middle-1970s, profoundly damaging consequences for the Arab states system. First, it generated deepened insecurity throughout the Arab world that intensified the retreat to statecentric self-help by the Arab states, notably Syria, while disillusioning the PLO that Palestinian interests could be peacefully attained. The first and most destructive symptom of these tendencies was the Lebanese civil war, unleashed by conflicts over the Palestinians in Lebanon. The Sinai II agreement sparked a showdown between a coalition of Palestinians and radical Lebanese Muslims who wanted to challenge Israel in southern Lebanon and Maronite Christians determined to eradicate this disruptive threat to Lebanese sovereignty. At the same time, Syria, left extremely vulnerable to Israeli power by the collapse of its Egyptian alliance and seeking to redress the imbalance, tried to use the Lebanese civil war to impose its leadership in the Levant, especially on Lebanon and the PLO. This precipitated a PLO-Syrian conflict that would never be wholly healed. ${ }^{45}$

Thus, if, in the 1973 war, co-operation between the Arab states benefited all, thereafter--caught in a classic prisoner's dilemma--none could trust the other not to seek individual gains unilaterally. While the Arabs as a bloc may have had the leverage to extract a comprehensive settlement if no one of them settled for less, Kissinger's step-by-step diplomacy had divided them and henceforth forced them to individually play weakened hands in negotiations with Israel. Even as Nasserite Egypt's hegemonic role had established Pan Arab constraints on sovereignty, Egypt's promotion under Sadat of sovereignty over Arabism released many remaining such constraints. The parallel popular disillusionment with Arabism further released constraints on the conduct of realpolitik by individual states. 46

\section{The $5^{\text {th }}$ Arab-Israel War (1982)}

Yet, the vacuum left by the decline of Arabism was not simply filled by greater identification with the individual states but even more so by heightened identification with either smaller sub-state identities or with the larger Islamic umma, the latter particularly heightened by the Iranian Islamic revolution. Indeed, there were failed Islamic uprisings in both Syria and Egypt at the end of the decade. As Meridi Nahas ${ }^{47}$ argues, the decline of Pan Arabism made regimes especially vulnerable to revolutionary Islam because the same grievances that had fuelled the rise of Pan-Arabism-above all Israel's denial of Palestinian rights--persisted. The most powerful manifestation of this tendency would be the rise of Hizbollah, precipitated by a convergence of the 1979 Islamic revolution in Iran and the 1982 Israeli invasion of Lebanon.

At the same time, in Israel the irredentist right was strengthened. The Labour party's relative failure in the 1973 war shattered its traditional dominance of Israeli politics and shifted the Israeli political spectrum toward the Likud Party and the militant settler movement, Gush Emunim, which promoted illegal settlements in the occupied West Bank. Settlements increased threefold and settlers tenfold while Israeli acquisition of land and control of water resources was greatly accelerated. ${ }^{48}$ Likudist

\footnotetext{
${ }^{45}$ Smith, Palestine and the Arab-Israeli Conflict, pp. 242-253; Barnett, Dialogues in Arab Politics, pp. 191-200; Sela, The End of the Arab-Israeli Conflict, pp. 153-213.

${ }^{46}$ Barnett, Dialogues in Arab Politics, pp. 206-207; Sela The End of the Arab-Israeli Conflict, pp. 189-213, Patrick Seale, Asad: the Struggle for the Middle East, Berkeley, University of California Press, 1988. 47 Nahas, Maridi (1985), 'State systems and revolutionary challenge: Nasser, Khomeini and the Middle East,' International Journal of Middle East Studies, 17:4, 507-27.

${ }^{48}$ Don Peretz, 'Israeli policies toward the Arab states and the Palestinians since 1967,' in Yehuda Lukas and Abdalla M. Battah, The Arab-Israeli Conflict, pp. 33-35; Roberts, Party and Policy in Israel, 45-88.
} 
Israeli Prime Minister Begin decreed the annexation of Jerusalem in 1980 and of the Golan Heights in 1981.

As a result, the 1980, Egyptian-Israeli peace treaty, instead of being the first step in a phased ending of the Arab-Israeli conflict, merely displaced the battle-lines toward the occupied West Bank/Gaza and to Lebanon. The PLO, expelled from Jordan in 1970, had in the following decade entrenched itself in Lebanon from which it sought to carry on a desultory guerrilla war against Israel. Israeli retaliation against Lebanon was a major factor in sparking the Lebanese civil war and this war, in turn, allowed the emergence of a PLO 'state-within-a-state' in southern Lebanon, precipitating an Israel's 1978 establishment of a strip of southern Lebanon as a "security zone." This, followed by the removal of Egypt, via its separate peace, from the Arab-Israeli power balance, and the election in Israel of an even more radically irredentist leadership, including Begin, Defence Minister Ariel Sharon, and Foreign Minister Yitzhak Shamir, set the stage for Israel's 1982 invasion of Lebanon.

The Likud government's aim was to establish unchallenged regional hegemony by smashing the PLO and punishing Syria, perceived as the last obstacles to its incorporation of the West Bank and Golan into Greater Israel. It aimed to drive both out of Lebanon and impose a client regime in Beirut, thereby isolating and encircling Syria. ${ }^{49}$ The attempt failed and, indeed, precipitated a balancing reaction: Syria's a military build-up created a deterrence relation with Israel ${ }^{50}$ that kept the Golan Heights front quiet; but at the same time the invasion, gave rise to Hizbollah, a much more effective asymmetric threat to Israel than the PLO had ever been and whose guerrilla warfare forced Israel to abandon its occupation of southern Lebanon in 2000. However, the failure of the invasion did not, on the whole, empower doves in Israel and, except for brief interludes in which more conciliatory Labour governments explored the peace process, the irredentist right would continue its dominance of Israeli politics for the next three decades, inexorably pursuing the settlement of the West Bank, creating the "facts on the ground" that would make a land-for-peace political settlement nearly impossible.

\section{Conclusion}

The 1967 Arab-Israeli war was neither wholly a war of choice/opportunity or of vulnerability. For Israeli elites, it was an opportunity to end Israel's strategic vulnerability by acquiring more defensible borders and force its acceptance in the region. The actions Arab leaders took, which gave Israel an excuse to go to war, issued from vulnerability rooted in the regional power struggles in which firmness against Israel was essential to legitimacy; this resulted from the rise of Pan-Arab nationalism and the inter-Arab rivalry played out through dangerous 'outbidding' and brinkmanship.

The consequences of war furthered divergence rather than stimulating convergence between Israel and the Arabs. On the Arab side, defeat in 1967 ushered in the decline of Egyptian hegemony and of Arab nationalism as a hegemonic ideology. The 1973 war precipitated a second watershed, Arab official acceptance of peace with Israel. These two wars initiated a transition toward a more multi-polar state-centric system in

\footnotetext{
${ }^{49}$ Zeev Schiff, Zeev and Ehud Ya'ari, Israel's Lebanon War, (New York, Simon \& Schuster, 1984) pp. 31-43, 71-77; Peleg, "Impact of the Six-Day War," p. 64; Smith, Palestine and the Arab Israeli Conflict, pp. 267-270; Seale, Asad, pp. 373-376.

50 Yair Evron, War and Intervention in Lebanon: the Israeli-Syrian Deterrence Dialogue,

Baltimore: Johns Hopkins University Press, 1987
} 
which identity became more state-centric in the Arab world and individual state interests eclipsed the putative Arab national interest in shaping their foreign policies. The resultant Arab inability to combine against Israel shifted the power balance permanently toward it. The outcome also differentiated the Arab states' approach to Israel: Egypt's peace made it "status quo while the continued Israel occupation of Syrian territory (Golan Heights), kept a residual revisionism in Damascus's foreign policy. Nonstate actors, from the PLO and Hamas to Hizbollah also remained revisionist.

Overwhelming victory made Israel more secure but also more confidant it could impose its wishes militarily. This led the Arab front-line states to seek to redress the military imbalance, leading directly to the 1973 war, which partly righted the power balance and pushed Israel to reach a separate peace agreement with Egypt. This, however, left Syrian and Palestinian grievances unresolved and, in taking the largest Arab power out of the power balance with Israel, greatly reduced Arab leverage. But, again, the imbalance in Israel's favour was insufficient to impose a pro-Israeli peace; rather the war-inducing power transition scenario was reproduced. Israel made another attempt in 1982 to break the stalemate; but its failure in this war only restored a balance of frustration in which no side could achieve its objectives, leading to periodic further rounds of fighting which did nothing, either, to settle the world's most intractable conflict. 